\title{
Analisis Kebijakan PT Siantar Top Tbk terhadap Upaya Meningkatkan Produktivitas dan Hasil Pendapatan
}

\author{
Kevin Tjoa ${ }^{* 1}$, Bastanta ${ }^{2}$, Eric Marthino ${ }^{3}$, Elvin Amadeus Zhou ${ }^{4}$, Hery Haryanto ${ }^{5}$ \\ 1,2,3,4,5Management, Fakultas Ekonomi, Universitas Internasional Batam, Indonesia \\ Email: ${ }^{1}$ kevinchua564@ gmail.com
}

\begin{abstract}
Abstrak
PT Siantar Top Tbk merupakan salah satu perusahaan yang bergerak di bidang industri olahan makanan ringan di Indonesia. Siantar Top diketahui mengalami hambatan pada produktivitas dan hasil pendapatan yang mempengaruhi operasional usaha akibat pengaruh masa pandemi. Sehingga, perusahaan menerapkan berbagai macam kebijakan agar mengembalikan stabilitas proses bisnis Siantar Top. Penyusunan makalah ini bertujuan untuk mengetahui analisis kebijakan PT Siantar Top Tbk terhadap upaya peningkatan aspek produktivitas dan hasil pendapatan usaha. Hasil penyusunan makalah menunjukkan adanya upaya Siantar Top mengendalikan kestabilan usaha dengan kebijakan baru selama masa pandemi untuk penyelesaian masalah perusahaan.
\end{abstract}

Kata kunci: Ekonomi Mikro, Hasil Pendapatan, Kebijakan, Produktivitas

\section{Abstract}

PT Siantar Top Tbk is a company engaged in the snack food industry in Indonesia. Siantar Top is known to experience obstacles to productivity and income results that affect business operations due to the influence of the pandemic period. Thus, the company implements various policies in order to restore the stability of Siantar Top's business processes. The preparation of this paper aims to determine the policy analysis of PT Siantar Top Tbk towards efforts to increase aspects of productivity and operating income. The results of the preparation of the paper show Siantar Top's efforts to control business stability with new policies during the pandemic to solve company problems.

Keywords: Income Generation, Microeconomics, Policy, Productivity

\section{PENDAHULUAN}

Kegiatan usaha selalu memiliki konsep bisnis yang mengarahkan untuk setiap tahapan aktivitas yang dikerjakan dalam mencapai tujuan tertentu yang biasa disebut dengan proses bisnis. Rummler dan Brache dalam (Bandiyono, 2017) menyebutkan bahwa proses bisnis merupakan suatu aktivitas usaha guna mengolah produk yang menghasilkan barang dan jasa untuk digunakan target pelanggan tertentu dalam memenuhi kebutuhannya (Ahmad\&Kurniawan, 2020). Sehingga, hal tersebut memicu adanya kebijakan usaha yang mendorong produktivitas kegiatan bisnis agar mencapai hasil pendapatan yang diinginkan(Ahmad Zaini\&Kurniawan, 2017).

PT Siantar Top Tbk adalah salah satu perusahaan yang berdiri di Indonesia dengan fokus sebagai produsen di bidang industri makanan ringan seperti snack, permen, mie, cracker, dan jajanan kecil lainnya. Siantar Top didirikan pada tahun 1972 oleh Shindo Sumidomo yang dimulai dengan usaha rumahan, kemudian seiring berjalannya waktu pada tahun 1987 usaha ini mengalami perkembangan yang cukup pesat sehingga terbentuklah PT Siantar Top Industri dengan pabrik pertama seluas $25.000 \mathrm{~m}^{2}$ yang terletak di Tambak Sawah, Sidoarjo. Sedangkan, pada tahun 1996 tercatat bahwa PT Siantar Top menjadi perusahaan publik yang masuk dalam data Bursa Efek Indonesia sehingga dikenal dengan nama perusahaan seperti sekarang ini (Siantar Top, 2021).

Dalam melaksanakan aktivitas usaha Siantar Top tentu memiliki berbagai macam kebijakan yang diterapkan pemilik usaha untuk meningkatkan produktivitas dan hasil pendapatan. PT Siantar Top Tbk diketahui terdapat beberapa prinsip tata kelola perusahaan sebagai upaya kebijakan agar kegiatan usaha 
bersifat konsisten diantaranya seperti Prinsip Keadilan sebagai kepentingan meningkatkan kinerja perusahaan dengan memberikan perlindungan asuransi pada mesin produksi, bangunan, dan persediaan; Prinsip Keterbukaan dan Pengungkapan sebagai pengelolaan seluruh laporan keuangan perusahaan terhadap pihak berwenang seperti OJK, BEI, dan surat kabar nasional; Prinsip Akuntansi sebagai pengelolaan dan pengawasan kegiatan pemegang saham perusahaan; Komisaris sebagai pihak pengambil keputusan untuk seluruh kepentingan perusahaan yang bersifat tepat dan cepat (Siantar Top, 2021).

Namun, selama Indonesia mengalami penyebaran wabah virus COVID-19 sejak awal Maret 2020 hingga saat ini diketahui bahwa PT Siantar Top Tbk terkena dampak untuk seluruh proses bisnis perusahaan yang mengalami beberapa hambatan, sehingga kegiatan usaha tidak mampu mencapai target pemasaran dan penjualan produk yang diinginkan. Hal ini dibuktikan dari adanya ancaman yang mempengaruhi kinerja Siantar Top terutama pada rencana membuka pasar ekspor baru yang berfokus meratakan pasar di kawasan Asia Timur seperti Korea Selatan dan Taiwan (Dewi, 2020). Sehingga, menghadapi permasalahan ini menyebabkan PT Siantar Top Tbk menerapkan kebijakan baru sementara guna mendorong produktivitas dan hasil pendapatan selama masa pandemi COVID-19 di Indonesia.

Oleh karena itu, sesuai latar belakang masalah yang telah dijabarkan penulis maka akan dilanjutkan pembahasan lebih dalam tentang proses bisnis serta kebijakan produktivitas dan hasil pendapatan PT Siantar Top Tbk di tengah masa pandemi COVID-19 dalam penyusunan makalah ini.

Sesuai dengan penjelasan latar belakang yang diuraikan oleh peneliti, maka diambil beberapa tujuan penelitian sebagai berikut:

1. Menganalisis proses bisnis yang diterapkan PT Siantar Top Tbk selama masa pandemi COVID-19.

2. Menganalisis masalah proses bisnis yang dihadapi PT Siantar Top Tbk selama masa pandemi COVID-19.

3. Menganalisis penyelesaian masalah proses bisnis yang dihadapi PT Siantar Top Tbk selama masa pandemi COVID-19.

4. Menganalisis kebijakan penanganan produktivitas dan hasil pendapatan proses bisnis PT Siantar Top Tbk selama masa pandemi COVID-19.

\section{PROSES BISNIS}

\subsection{Proses Bisnis PT Siantar Top Tbk}

PT Siantar Top Tbk dikenal memiliki tahapan kegiatan usaha mulai dari memproduksi produk hingga menawarkan produk agar dapat diterima oleh target konsumennya. Hal ini membuat sistem operasional perusahaan Siantar Top menerapkan alur proses bisnis sebagai bentuk pengawasan dan penyelarasan setiap tahapan dari awal hingga akhir bisnis dapat dilakukan dengan baik oleh masingmasing pemangku kepentingan sesuai tugas dan tanggung jawab yang diberikan (Ericsson, 2021). Berikut ini adalah beberapa alur proses bisnis PT Siantar Top Tbk meliputi:

1. Membeli Bahan Baku Produksi Pada Pemasok PT Siantar Top Tbk

Siantar Top memiliki hubungan kerja sama dengan beberapa pemasok bahan baku untuk mengelola produksi makanan ringan yang akan ditawarkan pada target pelanggan masyarakat Indonesia. Sehingga, perusahaan selalu membeli pada pemasok yang telah dipercaya dengan bahan baku yang berkualitas dan mutu tinggi sehingg mempengruhi hasil akhir dari produksi perusahan.

2. Mengolah Bahan Baku Menjadi Hasil Olahan Produksi PT Siantar Top Tbk

Siantar Top setelah menerima seluruh bahan baku yang diperoleh dari pemasoknya diketahui tidak langsung melanjutkan pada proses produksi melainkan tahap pengamatan bahan baku yang telah diterima dengan pengambilan sampel secara acak untuk penelitian di laboratorium sebagai upaya untuk memastikan bahwa setiap panen telah teruji secara klinis dan layak untuk diolah menjadi produk makanan atau minuman yang kebutuhannya ditentukan oleh perusahaan. Jika hasil uji laboratorium dinyatakan aman maka tahap produksi dapat dilakukan hingga selesai. PT Siantar Top Tbk menetapkan aturan untuk pengamatan ini agar seluruh hasil produksi tetap aman hingga sampai di tangan pelanggan. 
3. Mengamati dan Mengawasi Hasil Produksi PT Siantar Top Tbk

Siantar Top terus mencermati dan mengawasi seluruh produk olahan yang siap dipasarkan atau sebaliknya. Hal ini sebagai upaya untuk menghindari kegagalan atau cacat produk yang tidak terpasarkan dengan baik kepada pelanggan karena akan berakibat pada berkurangnya nilai kepuasan pelanggan, serta memicu tanggapan bahwa perusahaan tidak memiliki standar yang cukup tinggi dalam mengelola kepentingan produk.

4. Mengemas Hasil Produksi PT Siantar Top Tbk

Siantar Top melakukan pengemasan di pabrik dengan menggunakan dua sumber daya perusahaan berupa tenaga manusia dan teknologi yang dipadukan untuk mencapai target pengemasan sesuai peraturan perusahaan. Selain itu penggunaan tenaga manusia juga untuk memonitor error mesin yang dialami oleh teknologi yang digunakan oleh Siantar Top, begitu juga sebaliknya. Tidak hanya itu, PT Siantar Top Tbk juga melakukan pengemasan dengan cukup unik dan menarik sehingga menjadi branding yang dapat membedakan merek Siantar Top dengan makanan ringan lainnya.

5. Menawarkan dan Memasarkan Hasil Produk PT Siantar Top Tbk

Siantar Top memasarkan seluruh produknya melalui iklan online atau media massa yang ditujukan untuk membidik peluang pasar yang lebih luas. Hal ini dilakukan perusahaan mengingat banyaknya pesaing di industri makanan dan minuman. Selain itu, PT Siantar Top Tbk memasarkan produknya dengan menawarkan dari retail kecil atau pasar tradisional hingga pasar besar, bahkan menjangkau pasar internasional. Hal ini juga mendukung kegiatan rencana Siantar Top yang akan membuka pasar ekspor di Asia Timur seperti Korea Selatan dan Taiwan.

6. Mendistribusikan Hasil Produk PT Siantar Top Tbk

Siantar Top memiliki tahap akhir pendistribusian produk-produk yang telah dipasarkan khususnya di seluruh Indonesia. Hal ini agar Indofood dapat membantu mendistribusikan kebutuhan makanan dan minuman masyarakat untuk kebutuhan sehari-hari. Selain itu, PT Siantar Top Tbk juga mempermudah aktivitas jual beli karena pelanggan dapat menemukan produk Indofood di toko terdekat

\subsection{Permasalahan Bisnis PT Siantar Top Tbk.}

PT Siantar Top Tbk diketahui memiliki hambatan yang dihadapi sejak mengalami masa pandemi COVID-19 di Indonesia pada awal Maret 2020 hingga saat ini. Hambatan dan kendala Siantar Top berdampak pada aktivitas proses bisnis terutama mempengaruhi kinerja karyawan yang mengalami penurunan motivasi dan semangat kerja. Sehingga, perusahaan juga mengalami kendala untuk memperluas target pasar ekspor secara internasional yang direncanakan akan mengirimkan hasil produk Siantar Top untuk pasar di Asia Timur terutama pada Korea Selatan dan Taiwan (Dewi, 2020).

Kinerja karyawan PT Siantar Top Tbk menjadi aspek penting karena bagian dari sumber daya perusahaan yang menopang seluruh kepentingan proses bisnis dari kegiatan usaha Siantar Top sejak awal produksi hingga pendistribusian hasil olahan produk pada target pelanggan masyarakat Indonesia. Siantar Top berupaya terhadap peningkatan motivasi kerja para karyawannya untuk menstabilkan dan mendorong setiap tahapan proses bisnis perusahaan.

Siantar Top juga mengalami masalah lainnya yang menghambat proses bisnis yaitu berkurangnya minat pembelian produk jajanan ringan oleh masyarakat Indonesia akibat pengaruh kebijakan pemerintah Indonesia yang membatasi aktivitas untuk keluar rumah, sehingga kegiatan belanja masyarakat juga mempengaruhi hasil pendapatan PT Siantar Top Tbk. Jumlah permintaan produk dari konsumen juga diketahui menurundan berubah akibat banyaknya perubahan kegiatan masyarakat yang hanya melalui rumah (Hidayat, 2020).

Tidak hanya itu, permasalahan lain yang dihadapi PT Siantar Top Tbk adalah proses bisnis untuk distribusi hasil produksi ke beberapa wilayah di Indonesia. Hal ini mengalami kendala akibat kebijakan pemerintah Indonesia berupa pembatasan untuk masuk ke wilayah kota lainnya, sehingga setiap aktivitas perusahaan harus memenuhi syarat jalur bisnis agar seluruh hasil produksi dapat menjangkau pemasok dan pelanggan sasaran (Ristyawati, 2020). 


\section{ANALISIS DAN KEBIJAKAN}

PT Siantar Top Tbk diketahui mengalami beberapa masalah terhadap proses bisnis usaha yang mempengaruhi produktivitas dan hasil pendapatan perusahaan. Sehingga, PT Siantar Top Tbk diketahui melakukan berbagai macam solusi untuk menyelesaikan permasalahan yang dihadapi terutama di tengah masa pandemi COVID-19 hingga saat ini.

Siantar Top mencatat bahwa terdapat permintaan pasokan hasil produk yang menurun di tengah masa pandemi. Hal ini menyebabkan perusahaan harus merancang pengelolaan strategi baru agar produk yang dipasarkan tetap dapat stabil seperti sebelum mengalami masa pandemi. Adapun PT Siantar Top Tbk untuk menyelesaikan masalah ini dengan mengupayakan fokus pada peningkatan kualitas pendistribusian atas stok produk di beberapa titik depo dan stock point yang telah bekerja sama dengan perusahaan (Hidayat, 2020). Perusahaan menjalankan startegi dengan mendekatkan produk pada target konsumen meski sedang berkegiatan melalui rumah dengan beragam penawaran menarik seperti memberi potongan harga atau bentuk promosi pembelian produk Siantar Top lainnya.

Hasil penyelesaian masalah jumlah permintaan produk tersebut telah berhasil dicapai PT Siantar Top Tbk sebab mampu memperoleh hasil penjualan lokal hingga bernilai Rp 1,64 triliun, dibandingkan dengan nilai penjualan ekspor Siantar Top yang hanya mencapai Rp 165,18 miliar. Melihat kemampuan PT Siantar Top Tbk dalam meneargetkan hasil pendapatan di tengah pandemi, maka perusahaan merencanakan target baru penjualan dengan nilai neto sebesar $10 \%$ pada akhir tahun yang telah ditentukan sesuai pergerakan pandemi COVID-19 (Hidayat, 2020).

Masalah lainnya yang dihadapi PT Siantar Top Tbk terkait kinerja karyawan yang berfokus pada produktivitas perusahaan juga didorong oleh perusahaan dengan merencanakan pengembangan dan pemberian motivasi semangat kerja bagi seluruh karyawan. Hal ini diupayakan PT Siantar Top Tbk dengan memberikan pemenuhan hak karyawan sehingga tiap individu pekerja mampu meningkatkan rasa kepuasan kerja yang bertujuan mendorong pembentukan sikap loyalitas pada perusahaan meski sedang mengalami masa pandemi COVID-19. Bentuk pemenuhan kepuasan para karyawan PT Siantar Top Tbk diberikan dengan memenuhi kebutuhan kesehatan untuk menjaga kekebalan tubuh saat bekerja saat pandemi; menaikkan nilai upah dan gaji yang menyesuaikan kinerja terhadap produktivitas Siantar Top; serta memberikan waktu libur secara bergilir saat pandemi mengingat adanya pembatasan kegiatan yang ditetapkan Pemerintah Indonesia.

Adapun hasil penyelesaian masalah kinerja karyawan terhadap produktivitas PT Siantar Top Tbk telah memberikan pengaruh yang mendorong kualitas kinerja karyawan lebih baik dibandingkan sebelumnya. Hal ini juga dibuktikan dari hasil pendapatan yang telah dicapai PT Siantar Top Tbk selama masa pandemi COVID-19.

Sesuai penyelesaian masalah PT Siantar Top Tbk diketahui bahwa perusahaan menerapkan kebijakan dengan fokus pada kinerja karyawan dan operasional usaha terutama pada kebijakan produktivitas dan hasil pendapatan agar tetap menstabilkan tujuan perusahaan dalam mencapai target penjualan di tengah masa pandemi.

\section{KESIMPULAN}

Berdasarkan penjelasan yang telah dijabarkan tentang proses bisnis PT Siantar Top Tbk selama masa pandemi dengan seluruh hambatan yang dialami maka ditarik simpulan bahwa perusahaan telah menyusun perencanaan dalam menghadapi seluruh masalah yaitu penurunan kinerja karyawan untuk produktivitas perusahaan, serta tingkat permintaan pasokan produk yang menurun untuk hasil pendapatan. Upaya yang dilakukan PT Siantar Top Tbk pada produktivitas kinerja karyawan dengan meningkatkan pemenuhan kepuasan karyawan selama bekerja di perusahaan, sedangkan pada hasil pendapatan untuk penjualan produk Siantar Top dengan melakukan pendekatan produk terhadap pelanggan masyarakat Indonesia.

Berdasarkan hasil penjelasan yang telah dipaparkan maka penulis ingin memberikan beberapa rekomendasi untuk kepentingan seperti bagi PT Siantar Top Tbk yaitu untuk meningkatkan upaya produktivitas bagi kinerja karyawan yang mempengaruhi hasil pendapatan penjualan produk. Sedangkan, bagi penulis di masa mendatang agar menggunakan sumber referensi data lainnya mengingat adanya kekurangan dalam menyusun makalah ini. 


\section{DAFTAR PUSTAKA}

Ahmad, A., \& Kurniawan, Y. I. (2020). Sistem Pendukung Keputusan Pemilihan Pegawai Terbaik Menggunakan Simple Additive Weighting. Jurnal Teknik Informatika (Jutif), 1(2), 101-108.

Ahmad Zaini, B. J., \& Kurniawan, Y. I. (2017). Sistem Kasir dan Pembukuan di Toko Bangunan" Murah" dan Penyewaan Sound System" Kurnia" (Doctoral dissertation, Universitas Muhammadiyah Surakarta).

Bandiyono, A. (2017). PROSES BISNIS SEKSI PENGAWASAN DAN KONSULTASI I DI KANTOR PELAYANAN PAJAK PENANAMAN MODAL ASING. Jurnal Aplikasi Bisnis 8, no. 1, 75-80.

Dewi, H. K. (2020, Maret 25). Ada ancaman virus corona, begini efeknya terhadap kinerja Siantar Top $(S T T P)$. Retrieved from KONTAN.CO.ID: https://investasi.kontan.co.id/news/ada-ancamanvirus-corona-begini-efeknya-terhadap-kinerja-siantar-top-sttp

Ericsson, H. M. (2021, Oktober 11). Proses Bisnis Indofood. Retrieved from kompasiana: https://www.kompasiana.com/marcelericsson/616415e706310e32c5183fe4/proses-bisnisindofood

Hidayat, K. (2020, Agustus 09). Selama pandemi corona, Siantar Top (STTP) perkuat distribusi produk. Retrieved from KONTAN.CO.ID: https://industri.kontan.co.id/news/selama-pandemi-coronasiantar-top-sttp-perkuat-distribusi-produk

Ristyawati, A. (2020). Efektifitas Kebijakan Pembatasan Sosial Berskala Besar Dalam Masa Pandemi Corona Virus 2019 oleh Pemerintah Sesuai Amanat UUD NRI Tahun 1945. Administrative Law and Governance Journal 3, no. 2, 240-249.

Siantar Top. (2021, November 08). Tata Kelola Perusahaan. Retrieved from siantartop: https://.co.id/id/hubungan-investor/tata-kelola-perusahaan/

Siantar Top. (2021, November 8). TENTANG SIANTAR TOP. Retrieved from siantartop: https://siantartop.co.id/id/tentang-kami/ 


\section{Halaman Ini Dikosongkan}

